\title{
CADEIA PRODUTIVA DO GENGIBRE (Zingiber officinale ROSCOE) NO ESTADO DO PARANÁ: ANÁLISE E RECOMENDAÇÕES PARA MELHORIA DA \\ QUALIDADE'
}

\author{
PRODUCTIVE CHAIN OF THE GINGER (Zingiber officinale ROSCOE) ON \\ PARANA STATE: ANALYSIS AND RECOMMENDATIONS TO IMPROVEMENT \\ FROM QUALITY
}

\author{
Eliane Rose Serpe ELPO 2* \\ Raquel Rejane Bonato NEGRELLE ${ }^{3}$
}

\begin{abstract}
RESUMO
O presente trabalho teve como objetivo o estudo prospectivo da cadeia produtiva do Zingiber officinale Roscoe no Estado do Paraná, identificando os principais agentes envolvidos e paralelamente proceder análise dos pontos de estrangulamentos, especificamente no que concerne à qualidade microbiológica deste produto em todos os níveis, desde a produção até a fase final da comercialização, visando identificar causas e propor soluções no sentido da melhoria do sistema como um todo. Este estudo foi desenvolvido no período de 2000 a 2002 englobando pesquisa de campo, entrevistas abertas com representantes de estabelecimentos de comercialização, produtores e demais atores da cadeia produtiva, além de análises laboratoriais do produto "in natura" disponível no mercado consumidor da Região Metropolitana de Curitiba - PR. Este documento está organizado em 9 capítulos, que apresentam vastas informações englobando aspectos botânicos, ecológicos, físico-químicos e farmacológicos do gengibre, e que estão incluídas nos capítulos 1 e 2 . O capítulo 3 apresenta características gerais da principal região produtora brasileira, Morretes - PR, englobando localização, aspectos sócio-econômicos, geológicos e geomorfológicos e caracterização climática. O capítulo 4 apresenta o estudo prospectivo da cadeia produtiva do gengibre no Estado do Paraná, que engloba panorama mundial, brasileiro e paranaense do volume de produção agrícola de gengibre. Inclui-se também caracterização da comunidade produtora agrícola do litoral paranaense, além da identificação e caracterização dos outros diferentes níveis da cadeia produtiva do gengibre e a detecção dos principais pontos de estrangulamento nos diferentes níveis desta cadeia produtiva. A caracterização do cultivo e beneficiamento do gengibre no litoral paranaense é apresentada no capítulo 5 , evidenciando suas particularidades frente ao descrito na literatura especializada. No capítulo 6 avaliou-se as condições higiênico-sanitárias dos estabelecimentos produtores, do processo de beneficiamento pós-colheita (lavagem, limpeza, secagem e embalagem) e das condições de manipulação do gengibre "in natura" no litoral paranaense. De maneira geral, as condições de higiene e limpeza observadas foram consideradas precárias, determinando alta potencialidade de contaminação do gengibre com agentes que poderiam colocar em risco a saúde do consumidor. No capítulo 7 são apresentados os resultados dos estabelecimentos de comercialização da Região Metropolitana de Curitiba - PR, no que tange à qualidade e adequação às normas vigentes. Dos aspectos observados, as condições dos vestuários e dos equipamentos de proteção individual (manipuladores) foram considerados precários, o que pode potencializar a contaminação do produto e colocar em risco a saúde do consumidor. O capítulo 8 teve como objetivo caracterizar o perfil microbiológico do gengibre "in natura" comercializado na Região Metropolitana de Curitiba - PR, tendo como base a Resolução - CNPPA n. 12 - Brasil, 1978 e a Resolução - RDC n. 12 - Brasil, 2001. Para tanto, foram realizadas a determinação do número mais provável (NMP) de coliformes totais, coliformes a 45 C/g e Escherichia coli, e a presença de Salmonella sp em 25 gramas. Sintetizando, um conjunto de propostas e recomendações aos agentes econômicos que atuam e processam a cadeia produtiva do gengibre no Estado do Paraná, em especial o município de Morretes - PR, é apresentado no capítulo 9.
\end{abstract}

Palavras-chave: qualidade, Zingiber officinale, cadeia produtiva.

\footnotetext{
${ }^{1}$ Resumo da Tese de Doutorado em Agronomia - Produção Vegetal, UFPR, defendida em 02 e março de 2004

${ }^{2}$ Doutora em Agronomia - Produção Vegetal. Professora do Departamento de Saúde Comunitária. Laboratório de Saúde Pública - Universidade Federal do Paraná, Rua Padre Camargo, 280 - 7º andar. Alto da Glória, Curitiba - PR, CEP: 80.060-240. e-mail: erselpo@ufpr.br

${ }^{3}$ Orientadora. Doutora em Ecologia. Professora do Departamento de Botânica. Laboratório OIKOS - Universidade Federal do Paraná, Centro Politécnico, Jardim das Américas, Curitiba - PR, Brasil. CEP: 81.531-990. e-mail: negrelle@ ufpr.br

${ }^{*}$ A quem a correspondência deve ser enviada.
} 
ELPO, E.R.S. e NEGRELLE, R.R.B. Cadeia produtiva do gengibre...

\begin{abstract}
Prospective studies of the productive chain of the Zingiber officinale Roscoe on Parana State identifying the main agents envolved and parallel procedure analysis of the strangulation points, in order to microbiology quality this product in whole levels from the production until commercialization last phase, aiming identify causes and propose solutions to the improvement of the system in general. This survey developed from 2000 to 2002 involved field research, interviews with representative of the commercialization establishments, producers and others actors of the productive chain, besides made in laboratories of the quality of crude product available to the consumer market in Curitiba. This paper is organized in nine chapters that present information involving botanical, ecological, physiquechemical and pharmacological aspects of ginger that are included in chapters 1 and 2 . The chapter 3 presents the characteristics of the main brazilian productive area, embody localization, social and economic aspects, geologycal, geomorphologycal and climate characterization. The chapter 4 the study of the productive chain of this product in Parana State, which includes the paranaense, the brazilian and the worldwide panoramic view of the production volume and commercialization of the ginger; characterization of the agricultural community; identification and characterization of others different levels of the productive chain and also, the main strangulation points on these different levels of the productive chain. In the chapter 5 the agricultural process of the ginger benefit and cultivation in Morretes Town, Paraná, Brazil was caracterized. In the chapter 6 the hygienic-sanitary conditions of the producers establishments, postharvest benefit system and manipulation conditions of crude ginger in the paranaense coastland, Brazil were evaluated with an aim to subsidy the ofert of the best quality product to consumer market. In general, the cleaning and hygienic conditions were precarious, determining a high potential of ginger contamination with agents that can put in risk the consumers' health. The chapter 7 presents the results of the commercialization establishments in the metropolitan area of Curitiba considering adequation to the current norm. Of the observed items, the manipulation conditions was considered precarious due to the inadequate conditions that contributes to contamination, bringing about serious problems to consumers' health.The chapter 8 aimed the microbiological quality of the ginger market in the metropolitan area of Curitiba based on the Brazilian legislation. The microbiological analysis found total coliforms, $45^{\circ} \mathrm{C} / \mathrm{g}$ coliforms, Escherichia colimost probable number (MPN) and Salmonella sp presence. Synthetizing, a group of considerations and recommendations to economic agents that actuate and carry on the productive chain of the ginger in the Parana State, specially in Morretes Town, is presented in the chapter 9.
\end{abstract}

Key-words: quality, Zingiber officinale, productive chain. 